\title{
超音波ドプラー法と超音波カルディオグラフィ法 の併用による非観血的心拍出量測定法
}

岡山大学医学部第 2 外科教室（主任：寺本 滋教授)

大屋厚 夫

(昭和55年 5 月 26 日受稿)

Key words : 非観血的血流量, 非観血的心拍出量, 超音波ドプラー法, 超音波カルディオグラフィ法

\section{1文相}

近年，方向指示型超音波ドブラー血流計によ る末梢動脈，ことに䊝頸動脈の血流波形と心拍 出量との関連を分析した報告がみられるように なった。これらの報告は非観血的に超音波ドプ ラ一血流計を用いて，血流速度を連続的に測定 しながら負荷を与えたり，術中，術後の心拍出 量の変化を経時的に追う方向の有効性を強調し ている.しかし、こうした測定法では精度に関 する限り，非観血的であるという理由からそれ 任と崖しい要求をなされていない。これらの久 点よりも経時的な相対変化を简単に，無侵撉で 追跡できるという他の追従を許さない特徴を活 用できるため，外科臨床においても，術後の患 者の経過観察の目的で心拍出量を知るための重 要なパラメーターとなりうることによって有力 な手段ときれてきた。

本研究は血流波形の分析のみならす，流量の 定量化を試みたもので，超音波ドブラー法と超 音波カルディオグラフィの組合せにより，一方 の短所を他方の長所で補うことで好結果を得た。 超音波ドフララー法で血流速度を経時的に計测し， 同時に超音波カルディオグラフィによってその 時々の血管径を計測し，波形の皘分により流速 を算出し，血管径より血管断面積を乗して血流 量の测定を試みた。

実駼方法は，左總頸動脈流量を中心に行い，流 量の基苝として電磁流量計を用いた。電磁流量 計によって得られな心拍出量と, 左綕頸動脈の
流量比の相関をだし，逆に左頸動脈の流量より 心拍出量の推定を行ったものである.

実稌犬数は15頭で，電磁流量計でえられた左 總頸動脈流量は超音波ドブラー法と超音波カル ディオグラフィ法によってえられた流量の相関は, $y=0.92 x-0.03, r=0.96, P<0.001$ と高い相 関関係を示し,さらに, この流量より心拍出量 を推定した10例では， $y=37.0 x+18.9(r=0.90$, $\mathrm{p}<0.001)$ の結果をえた。

本法の臨床応用にあたっては非観血的である だけに繰返し簡単に，しかも無侵撉に行いうる ものであり，術後患者の経過钼察のための重要 なパラメーターとして好結果を期待できるもの である。

\section{序}

心拍出量や身体各部の血流量を知るこをが臨 床的に重要であることは論をまたない。とくに 開心術患者の術前、術後の管理のための心拍出 量の測定は不可欠である. 閉塞性動脈硬化症や Buerger 病などの末梢動脈疾患でも患部の血流 量を知ることは重要である。ことに非観血的で あれば患者に苦痛や侵襲を与えることなく簡単 にしかも繰返し測定でき，理想的である。この 目的のために，従来よりドブラー法が至適と考 えられ，種々な方法が考案されているか，血管 断面皘を知る確実な手段を欠いていたため，定 量的な方法は開発されていない。

本研究はここに注目し，超音波ドブラー法に， 超音波カルディオゲラフィ法を組合せることに 
厚夫

よク，血流量を定量的に測定しようと試みたも のである，すなわち，超音波ドブラー法で血流 速度を経時的に計測し, 同時に, 同部で超音波 カルディオグラフィ法により，血管径を経時的 に計測し、これにより血管断面積を算出し, 湘 定部血管の血流量の定量化を試みた，使用血管 は左総頸動脈であり, 同血管の血流量の定量化 を試みると同時に, さらに大動脈起始部血流量 (心拍出量)を左総頸動脈の流量比の相関をだ し, 逆に左総頸動脈流量より心拍出量の推定も 試みた。本法により血流または心拍出量の定量 化が可能であることが判明した。

\section{实磁方法と萦而}

実験犬数は15頭である．体重15２0kgの成犬 にネンフタール $(25 \sim 30 \mathrm{mg} / \mathrm{kg})$ を静脈注射し， 全身麻酔を施し，右側卧位で固定した。気管内 扱管後, 従量式人工呼吸器 (五十峝医科工業, Model-B2）を用いて調節呼吸をおこなった.

第 4 肋間右側開胸をおこない，心素を柈切開 して大動脈起始部を露出し, 外径を実測（日本

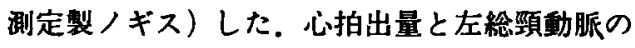
基準血流量は電磁流量計(日本光電工業製, Model, MF-27) で測定した. プローブは血管外径 より5 -10\%小きいものを用い，血管外径は血 管に䋖合系を巻き，糸の長さより求めた，総頸 功脈の基準血流量は左頸部を縦切開し, 左紷頸 功脈を蕗出し, 前記同様に電磁流量計のプロー フを装着し，大動脈流量と同時に記録した。さ らに双方の流速脈波形を圧脈波微分器（三栄測 器, 1309) に入力, 8 チャンネルポリグラフ(三 栄測器ポリクラフ 142-8 Visigraph FR-102)に 增幅，記録した（紙おくり速度: $5 \mathrm{~cm} / \mathrm{sec}$.). 左総钼動脈の血管外径は 5 回実測し, その平 均值とした。この実測後に血管の走行, 位置を 確認し, 左綕頸静脈と交差する部位を選U゙, 頸 部下半でドプラーのペンシル型プローブを設置 する部位を決定した．検波時の静脈血流による 雑音の影響をさけるための確認である（静脈の ものはコマ音様として㯖取されるので比較的容 易に判別できる). 電磁流量計のプロープを萃着 したままの状態で皮虎を絴合し，プローブの移 㗢を防ぐため絴合系により2 点を皮席に固定し，
流量が䋖合前と変化しないことを確認した.

超音波ドプラー法に上る血流速は方向指示型 超音波ドプラー血流計(Parks Electronics Lab. Blaverton, Model-806) を周波数 $9 \mathrm{MHz}$ で周 波数方式として雾交叉数計表示を用い，これに ペンシル型プローフ（直径 $5 \mathrm{~mm}$ ) を軽くおて, ドプラー音の最強点で血管のなす角が $60^{\circ}$ とな るよう固定して測定した。流速派波形はポリク ラフに, $25 \mathrm{~mm} /$ 秒および50 $\mathrm{mm} /$ 秒の速度で記録し た. 発信器 (Leader Electronic Carp LAG-25) で0点より $1 \mathrm{KHz}, 2 \mathrm{NHz}$ 単位でポリクララフに 記録した。また，ドプラー装置固有の雑音をし るため，安定した波形を描き，さらに波形が類 似している電磁流量計の流速脈波も同時に記録 した.こうして安定した脈波を最低 5 心拍とり， 混合流波形を記録した（図 1 ).

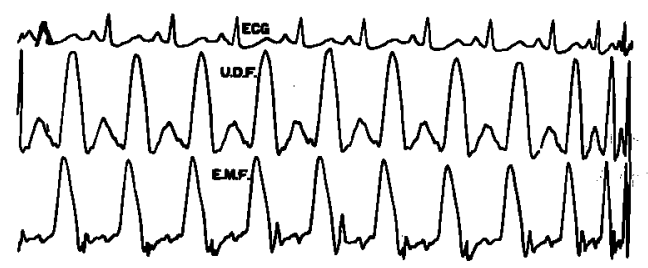

目 1 左総頸動脈におけるドブラー血流計 (U.D.F.) と電磁流量計 (E.M.F.) の流速脈波形の比 較.ドブラー血流計は混合脈波形で記睩。

超音波カルディオグラフィ法による血管径の 計測はトランスデューサー（K·B Aerotech 㱔， Model CT-22BS 2.25 MHz Short) と超音波力 ルディオグラフィ（三栄測器製, Model 2H-18) を用いておこなった. ドブラープローフで 計測した部位で, トランスデューサーの先端に ゼリーを塗布し, 皮度に軽くあて, 動脈性の拍 動を確認したのち, 少しづつ移動させながらオ シロスコープ上に表われる平行した 2 本線の拍 動波形が同一巾で表われるときを血管直上と判 断し，1秒間の露出で記録した (図2). 使用力 メラはアサヒ・ペンタックスSP型, マクロ・タ クマー, F4, $\mathrm{f}=50 \mathrm{~mm}$ ，ネオパン F (ASA 50) である。ささらに原版を等倍に应大し，ノギスに より血管壁厚を計測し血管外壁厚との差により 血管内径を求め，横断面を内形として断面積を 算出した。 
超音波ドプラー法と超音波カルデイオグラフィ法の併用による非観血的心拍出量測定法

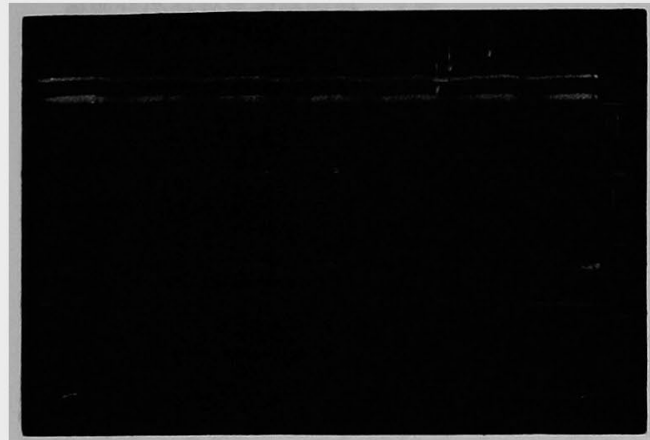

図2大盟助㟲 (径3 $\mathrm{mm})$ のオシロスコープ像. bからcまでを测定.

$$
\mathrm{fd}=\frac{2 \mathrm{~V}(\cos \theta)}{\mathrm{C}} \mathrm{f} \cdot \pi \mathrm{r}^{2}
$$

〔f：使用超音波周波数 ( $9 \mathrm{MHZ}), \mathrm{V}:$ 血流速 度, C：媒質中での音速 $(1500 \mathrm{~m} /$ 秒)， $\theta$ : 超音 波ビ一ムと流れのなす角 $\left(60^{\circ}\right), \pi \mathrm{r}^{2}$ 血管断面積了 方向指示型超音波ドプラー装置は周波数表示 方式として霉交叉数計表を用い，方向指示法は， Mc Leodの位相偏位方式を用いた。

超音波ドブラーの混合流速脈波を $50 \mathrm{~mm} /$ 秒 で 10心拍記録し，最も安定した状態でさらに雑音 のない脈波形を 5 心拍とり，0 点より先行 R-R 時間を 1 心拍として，その 1 心拍時間に等しい

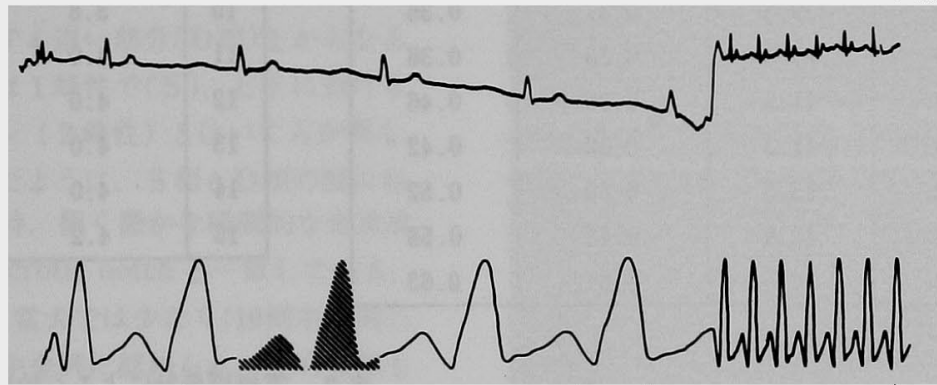

図 30 点より先行 R-R を 1 心拍として，その1 心拍時間に等しい脈波形の面積を示す. (斜線部). 流速は $17 \mathrm{~cm} /$ 秒。

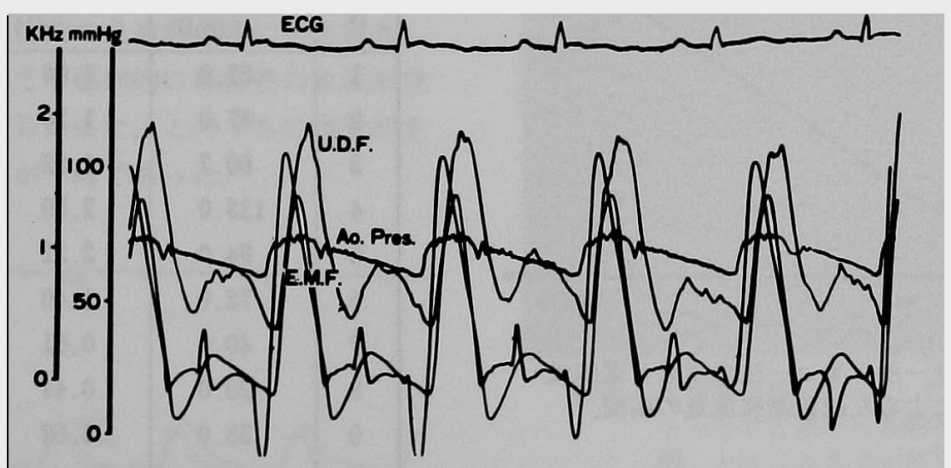

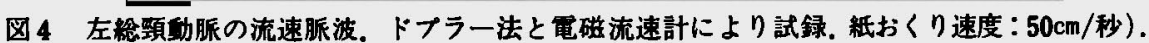

功脈圧と流量の関係をみるため，正常犬（ 5 頭）を脱血し，低血圧犬を作赀した。掫高血圧 を60mmHgとした，脱血は大概静脈よりおこな い，最高血圧が60mmHg となるまで脱血を行い， ショック状隼を作った．測定方法は前述の手技 でおこなった。

流量は容糟流速の樌分である，従って心拍出 量は大功脈流速と大助脈断面積の積を積分した しのに等しい，次式が成立し，これによって流 量を求めた（註).
脈波形の面積を積分計 (Ushikata 㱔 O-bacL. Planimeter）により，5脈波を求め，その平均 值を流速值とした（図3）.

註）表 1 のNo. 1 の流速脈波が図 3 で流速 V は $17.0 \mathrm{~cm} / \mathrm{sec}$. である. 絵钼動脈の計测值は 4.0 m⿰で血管断面棈， $\pi \mathrm{r}^{2}=3.14 \times(2)^{2}$ である，従っ て，これを前記の数式に代入し，単位を整理す ると次式となる。

$$
\mathrm{fd}=\frac{2 \times 17\left(\cos 60^{\circ}\right)}{150000} \times 9 \times 3.14 \times(2)^{2}
$$




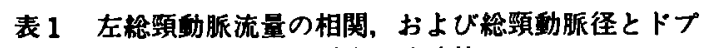
ラ一血流計による平均血流速值。

\begin{tabular}{|c|c|c|c|c|}
\hline $\mathrm{N}$ & $\begin{array}{c}\text { 総頸動脈径 } \\
(\mathrm{mm})\end{array}$ & $\begin{array}{c}\text { 血 流速 } \\
(\mathrm{cm} / \mathrm{sec})\end{array}$ & $\begin{array}{c}\text { ドプラー・エコー } \\
\text { 法によ流量 } \\
(\mathrm{ml} / \text { beat })\end{array}$ & $\begin{array}{c}\text { 電磁流量計 } \\
\text { (ml/beat) }\end{array}$ \\
\hline 1 & 4.0 & 17.0 & 0.68 & 0.80 \\
3 & 3.0 & 27.0 & 0.60 & 0.56 \\
4 & 4.0 & 19.5 & 0.76 & 1.06 \\
5 & 3.3 & 9.5 & 0.76 & 9.95 \\
6 & 4.0 & 18.0 & 0.76 & 9.75 \\
7 & 3.5 & 18.8 & 0.58 & 9.61 \\
8 & 3.8 & 34.5 & 0.44 & 1.43 \\
9 & 3.8 & 18.5 & 0.65 & 0.77 \\
10 & 3.6 & 9.5 & 0.31 & 0.36 \\
11 & 3.5 & 11.5 & 0.35 & 0.46 \\
12 & 3.5 & 11.2 & 0.32 & 0.42 \\
13 & 4.2 & 13.5 & 0.60 & 0.52 \\
14 & 4.0 & 12.0 & 0.48 & 0.58 \\
15 & 3.2 & 14.5 & 0.51 & 0.63 \\
\hline
\end{tabular}

表 2 総钼動脈血管径の計測值。

\begin{tabular}{|c|c|c|c|}
\hline \multirow{2}{*}{$\mathrm{N}$} & \multicolumn{2}{|c|}{ 血管 内 } & 径 $(\mathrm{mm})$ \\
\cline { 2 - 4 } & 計 側 值 & 実 & 測 值 \\
\hline 1 & 3.0 & 3.0 \\
3 & 3.2 & 3.4 \\
4 & 3.3 & 3.1 \\
5 & 3.5 & 3.3 \\
6 & 3.5 & 3.4 \\
7 & 3.5 & 3.4 \\
8 & 3.6 & 3.5 \\
9 & 3.8 & 3.6 \\
10 & 3.8 & 3.7 \\
11 & 3.8 & 3.8 \\
12 & 4.0 & 3.8 \\
13 & 4.0 & 3.8 \\
14 & 4.0 & 3.8 \\
15 & 4.0 & 3.9 \\
\hline
\end{tabular}

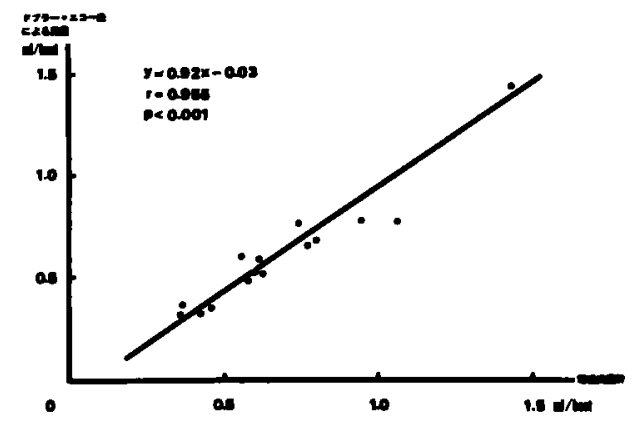

図 5 ドプラー法とエコー法の流量と電磁流 量計による左緑頸功脈流量の相関。

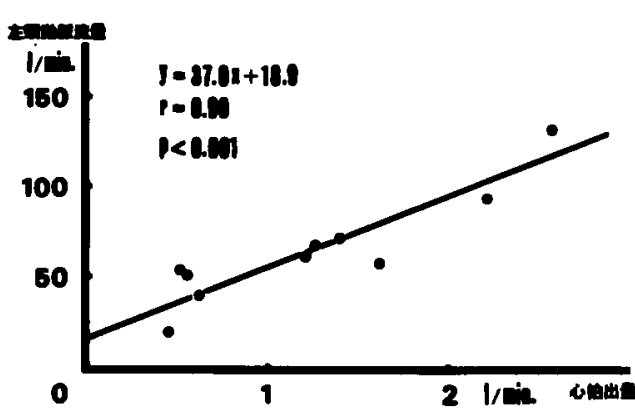

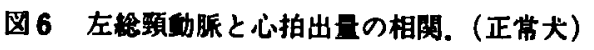

表 3 電磁流量計による心拍出量と左稳頙動 脈の流量比（正常犬）.

\begin{tabular}{|c|c|c|c|}
\hline $\mathbf{N}$ & $\begin{array}{r}\text { 䁰動㟲流量 } \\
(\mathrm{ml})\end{array}$ & 心拍出量 & 流量 比 \\
\hline 1 & 57.0 & 1.66 & 3.5 \\
\hline 2 & 67.0 & 1.28 & 5.2 \\
\hline 3 & 60.7 & 1.22 & 4.9 \\
\hline 4 & 133.0 & 2.59 & 5.1 \\
\hline 5 & 94.0 & 2.22 & 4.2 \\
\hline 6 & 72.0 & 1.40 & 5.1 \\
\hline 7 & 40.0 & 0.61 & 6.5 \\
\hline 8 & 20.0 & 0.44 & 4.5 \\
\hline 9 & 55.0 & 0.52 & 10.0 \\
\hline 10 & 52.0 & 0.54 & 9.6 \\
\hline
\end{tabular}

\section{索 的}

左総烦係脈の血流速をドプラー法で描写した のが困 4 である，表 1 は実験犬15頭の流量を示 したものである。エコー法を用いた血管往の测 定結果と実測值の結果は表 2 に示した。而者間 の相関係数は $\mathrm{r}=0.99$ である. 回㷌直線は $\boldsymbol{y}=$ $0.89 x+0.22 て ゙, \mathrm{p}<0.001$ で有意の相関がある. またドプラー法によってえられた流速值（5

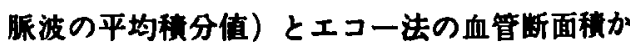


ら得られた流量と, 電磁流量計による流量の相

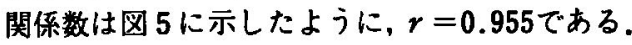
回㷌直線は, $y=0.92 x-0.03$ で, $\mathrm{p}<0.001$ で有 意の相関をえた。

左総頸動脈血流量から，心拍出量を推測する ため，正常犬10例と脱血犬 5 例について両者の 血流量を比較した(表 3 と 4 ). 平均流量比は5.9 \pm 2.2 (平均值士標準偏差) であった. 正常犬10 例について検討したが, 回㷌直線は $y=37.0 x$ $+18.9(r=0.90, \dot{\mathrm{p}}<0.001)$ であった(図 6 ).

ドブラー法の総頸動脈の流速波形の基本的パ ターンは心駆出期に相当する急速前進相 ( $\mathrm{S}$ 相) と心拡張期に对する遅い部分( D相)とからなる が, 急速前進相は 1 峰性で(S), ヒトにおける 䋓頸動脈パターン（2 峰性）とはいくらか異な る. 困3に示したように, S 相とD相の間に谷 がみられ、この時, 極く微かな瞬間的な逆流成 分がいづれも Dicrotic notch と一致している。 ただしこれは正常犬では少なく(10例中 3 例)， 脱血犬では 5 例中全例に認められ，その波形も 急速前進相のピークは低く（図7）, 波形もなだ らかとなる．逆流成分は末梢動脈血管では，一 眼拍周期として初期の急速前進相に引き続き, 心搪張期にあっても原則的に波動性の血流が存 在すること,さらにまた,このうちに逆流相を 含むものがあるが一瞬であった。
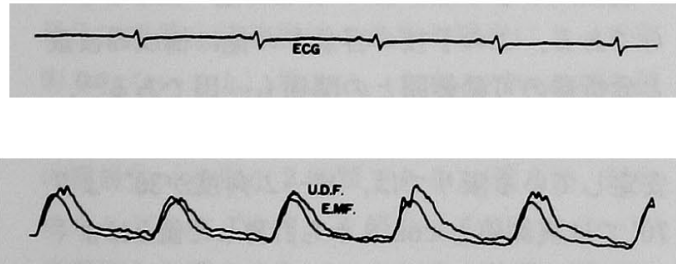

图 7 ショック犬による左悢頸勁脈のパターン

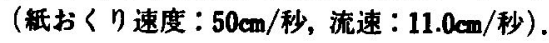

脱血によるショック犬は 5 例である．絵頸動 脈量は重症なショック状態においても无分な血 流量があり，その流量比は心拍出量低下と共に 正常犬に比べやや上昇し，平均流量比は9.3\%で 正常犬より3.4\%の上昇をみた（表4）。

エコー法による紷類動脈径は，一定の巾を有 する平行した線として認められる(図8).これ には拍功性の功きがある，最上部の直線は皮成
面を表わし，大腿動脈と総顆動脈では皮庙面よ

表 4 心拍出量と左総䫐動脈の流量比（脱血 ショック犬).

\begin{tabular}{|c|c|c|c|}
\hline $\mathbf{N}$ & $\begin{array}{r}\text { 钼動脈流量 } \\
\text { (ml) }\end{array}$ & $\begin{array}{r}\text { 心拍 出量 } \\
\text { (1) }\end{array}$ & 流量 比 \\
\hline 1 & 45.0 & 0.46 & 8.4 \\
\hline 2 & 52.0 & 0.51 & 9.6 \\
\hline 3 & 40.0 & 0.36 & 9.0 \\
\hline 4 & 23.0 & 0.32 & 10.4 \\
\hline 5 & 41.0 & 0.40 & 9.0 \\
\hline
\end{tabular}

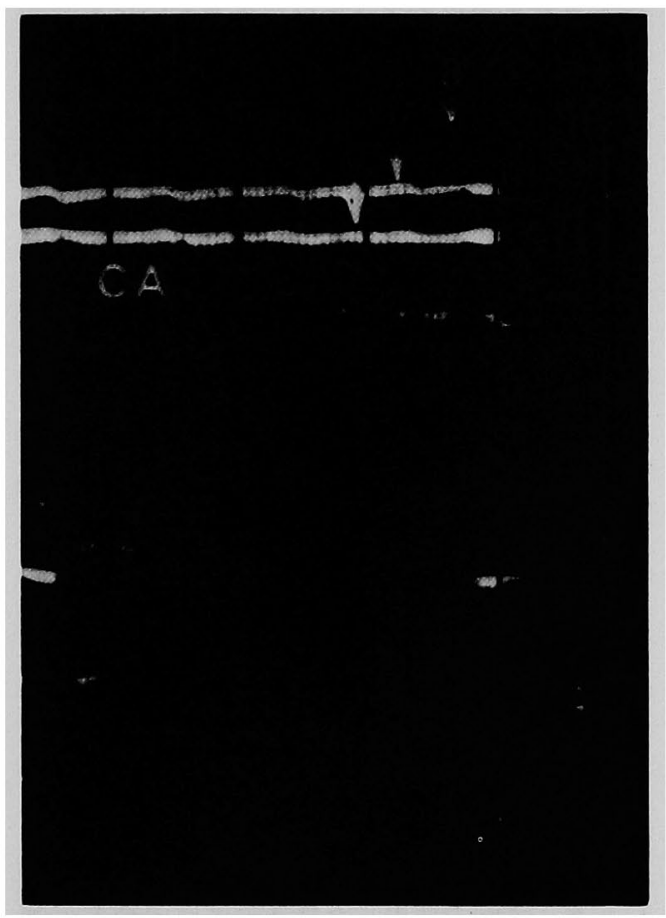

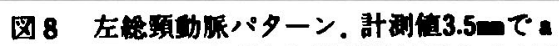
からbは皮庙から頝動脈外壁までの距 離. bから c までが血管径。测定策件 it Gain(-8), STC(0.4), Depth (3.0), Level (40), Speed (5.0), Meuge $(1 \mathrm{~cm})$.

クの樑さが異なる，さらに各々，特有な拍版性 の画像を示している。しかし，エコー法でえら れた血管径の経時的変化は心周期で極く微かで あり，したがって，流量への影整を与えるほど の血管内径の変化はなかった. (0.02m地)

超音波カルディオグラフィによる血管径の测 定は大钦脈や肺動脈でよく検討されている(1.2). 
しかし心周期による末梢動脈血管径の変動につ いての報告はない，末梢動脈（総頸動脈, 大腿 動脈）の超音波パターンは，平行する 2 本線と して描写され，動脈特有の波形が心周期に一致 してみえる（図2，8）。これはトランスジュー サーが血管の直上にある場合に限り描かれる画 像である。トランスジューサーが直上より一方 にずれると，平行する 2 本線の一方が細くなり， トランスジューサーが直上でないことを示す。 したがって血管の正確な直径を知るためには平 行する 2 本線のエコー反射が等浱度になるよう にすることが肝要である．図8は総頸動脈のMmodeによるものでS，およびDの点はそれぞれ 収縮期，搪張期である。一般には動脈血管は心 の収縮期には拡張し，拡張期には収縮するとさ れている。しかし肺動脈などの大血管での血管 径の変化は， $2 \mathrm{~mm}$ 以下であったという実験があ $3^{2}$. 本研究で計測した末梢動脈血管の徍変化は 収縮期，拡張期，いづれにおいてもみられなか った，しかしエコー図をみる限りでは，極く微 かな拍動運動はあるようである。ささらに，エコ 一像が最も得られやすい大腿動脈で検討しても 同様なパターンがえられた。 その結果心周期に よる末梢動脈の血管径の変化は僅少であり，し たがって血管断面積の変化も裉めて微量である ことが判明した。

血流速度を正確に測定するためには，ドブラ 一,プローフが血管となす角を正確に知ること が不可欠である．赛験モデルでは，容易に決定 しうる，実験で使用した総頸動脈は同動脈が浅 在性で，しかも皮下をほほ平行に走行するため である。しかしながら非侵襲性の臨床応用では 血管と一定の角度が保持されているかの確認が 不可能である。そこで, 本研究では超音波カル ディオグラフィによる確認をおこなった，図8 に示したように皮席面 a から総頸動脈前壁bま での深さを測りここの点を中心に末梢側と中枢 㑡との 2 点で同様に検波することにより，これ ら 3 点が皮庯面と同じ梁さであれば，皮席面と 平行して走行しているかどうかを視賞的に知る ことができる．血管が皮庙と平行して走行して いるという条件を満たした部分があれば，この 中心点から検波することで入射角を一定にする
ことができる。

通常，ドプラー法によって末梢動脈を検波す るとき，血流ドプラー唸の最強点のみを手がか クとして, 波形を求める。しかし, 血管断面に おいて，全ての血球が同じ流速をもつものでは ないことはドプラーのスぺクトログラムによっ て判明している27)，種々の速度をもつ血球が存 在することは明らかで, ことに血管壁附近を流 れる血球と中央を流れる血球とでは流体力学的 にも流速の遅速があることは充分に考えられる。 したがって，血管内を流れる血球を検波するの に，血管の直上でプローフが照射されていない場 合，その流速脈波が一方に偏することにより起 こる精度への影響はさけられない。プローフが 血管の直上でなければ流速脈波は不安定な波形 として現われるので安定した波形のみを对象と し，さらに波形の解析も試みた，周波数計によ る方法の出力の波形と, 電磁流量計の出力の波 形の比較や実際の流量との比較をしたが，よく 一致した結果をえた。

実際の計測では，ビームを血管の直上で照射 することが, エコー法，ドブラー法のいづれに おいても必要不可欠な条件であることは前述し た. さらにドプラー法で重要な点は入射角度で あろう. 本研究では入射角度を $60^{\circ}$ と設定した。 ビ 一ム巾と血管径がほは等しければ, ドでラー音 が最強点となる点が $60^{\circ}$ に非常に近い值となるか らである。この手技の容易さの他に構成周波数 と分析器の可動範囲との関係も一因である ${ }^{27)}$, 直流の定常流によるモデル実駼で，流れが充分 安定している限りでは，ビーム角度が30 より $70^{\circ}$ では実測値と $\cos \theta$ から計算した值とはよく 一致する。しかし，それより角度が大となれば， 実測值よりも大きくなり，角度が90になるとか なり大きい，また，それとともに流れが一方向 の直流であるにもかかわらず, 反对方向の出力 もえられはじめる。奾の理由により入射角度 を $60^{\circ}$ と設定した。この現象はビームの搪がりが あるためと解釈され，その搪がりの部分が流れ を迎え，また見送る結果であると考えられる。 本実験で10例中 3 例にこの逆流成分が記䩮され た. 入射角が血流走行に对し大きくなればなる ほどブラー出力は減少するが，各角度間におけ 
る出力差の分離は容易になるため近年, 角度依 存性のない血流速度测定法が実験的に試みられ ている ${ }^{28)}$. すなわち、a）2本のプローフを直角 に組合せる，b） 2 本のブローブを鋭角で組合 せる、c) パルス・ドプラー法（3ビームによ る三次元情報)。d）パルス・ドプラー法 (血流 までの距離测定）との併用.などである，a）

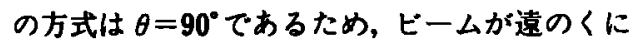
従い，分離する，したがって血管までの距噰に 影暨される.また，フローフが大型となり，扱 い難い欠点がある，b）はプローフを鋭角で固 定し，よって精度を高め，小型化し，比較的と ク报い易い. 現在考えられるこの方式が最も精 度が高いが浅在性の血管だけに限られる。c） はパルス法で血管の位置を計測したのち血流を 計測する方式で，血管の位置によっては血流計 測の䛊差にも新たな要素を含むことが考えられ る.ただし，ドプラー・アンギオグラフィィと の併用も考えられるが，装置が梗めて大がかり になる，d）は順流，逆流，混合流と複雑な流 れに対しても，䊉対流速が計測できる利点があ るが, c ) のように, パルス法であるため装置 の複誰化とプローフ大ききのための欠陥があ る. 以上が現在考えられる角度依存性のない方 法である．本実験で角度依存性のある装置を使 用した理由は，ます，第 1 に最もシンブルで複 雑化に併う不明な雑音が少ないこと，ことに定 量化に重要な流速脈波の波形が雑音によって変 形されないこと，第 2 に，2本のプローフを使 用することにより，取り扱い不便さと波形処理 の複䧴化 (波形が 2 種類できる), 第 3 に, 超音 波カルディオケラフィと組合せることによって 皮用面と血管の走行，およびその位置が確認で き，常に安定した計测部位を知ることができる こと，すなわち，多少精度が低下しても，常に 同一条件で測定でき，安定した結果が得られる というのが最大の利用理由である。本研究の最 的目的か開心術後の心拍出量の測定であるか ら、ベンシル型プローフと同梯な小型平板型プ

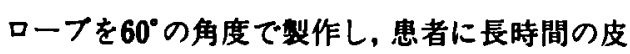
店固定できることがより重要な条件となる。計 測するたびごとに，扱い難いプローフを使用す ることは少なくとも術後管理には不道当と考える.
超音波ドプラー血流計による紷顽動脈のパタ ーンについて考察すると，本実駼では大動脈起 始部における電磁流量計での血流は駆出期の前 進相だけである．このことから，末梢動脈で拡 張期にも逆流が存在するのは，心䑏駆出現象と は関係なく、末梢動脈の血管の弾性、あるいは 低抗などが考えられる．しかし，これらの成分 と考之合せての流速脈波の積分值は逆流相が極 く微量であることと、ドフラー装置が ZCC 法 であるから、ドプー信号 (広带域信号) を有 限時間で記録することにより起こる本質的な出 カのゆらぎ (10\%以内) などの諸条件を考虑し て，筆者は 5 脈波の加算平均化を行った。

電磁流量計を用いて測定した心拍出量と，エ コー法とドブラー法を併用して測定した総頸動

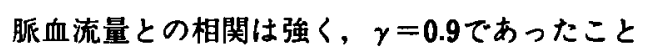
はすでに述へた. 左総頸動脈血流量と 1 回拍出 量 (大動脈起始部流量) の比は5.9土2.2であっ た. 脱血による Hypovolemia 時の棯頸動脈流 量と心拍出量との相関をショック犬で調へ，そ の流量比が9.4であることが判明した（表 4 ）. しかし, ヒトの流量比は改めて設定する必要が ある。さらに動脈硬化による血管壁の硬化がも たらす脈波伝播速度も関係するであろう。流量 そのものもある程度, 変化するであろうことは 充分に考えられる.加令により血流パターンの 変化が最も大きくあらわれるのは総頸動脈であ $\eta^{2124)}$ ，ことに老年層には血流パターンの平低 化がある。これは伸展性が減少していることが 原因であろう。本研究は正常な血管を对象とし たので2.25 MHz のトランスジューサーを使用 したが，紷頸動脈の硬化などにより血管内㓐の 状態が不明な症例は分解能の高い $5 \mathrm{MHz}$ ，ない し $10 \mathrm{MHz}$ のエコー・トランスジューサーを使 用すべきであろう。また薬物の投与により，拍 出量と頸動脈流量との比が変化する可能性は立 分に考えられるが、今後に残した問題である.

雑種成犬を用いて方向指示型䂏音波ドプラー 血流計と超音波カルディオグラフィ法との組合 せにより，左紷頸動脈血流量を非侵襲的に测定 し,この流量より1回心拍出量の推定を試みた。 
本研究は血流量が平均動脈流速の稹分值に動 脈断面積を乗じたものであるという作業仮設に 基づいて実験をおこない，生体において良好な 成績を修め，非観血的血流測定法として有望で あることを確認した。

1) 実際の臨床計測ではZCC 法でドプラー 信号を有限時間で処理することに併う本質的な 出力のゆらぎあるいは雑音成分を考虑しても なお10\%前後の誤差はきけられないと考えねば ならない.

2 ) ドプラー血流計における入射角の問題点, 入射角 $60^{\circ}$ で設定したものが $10^{\circ}$ 前後に変化する ことにより，少くとも流量は10\%の誤差を生ず ることから，2本のプローブによる角度依存性 のない方法でプローブが皮庙面に長時間固定で きるような小型化したものに改善されるなら， 超音波カルディオグラフィとの組合せにより精 度はさらに高いものが期待できる。

3）計測部位は血管の極く限られた一点の流 量ではあるが, 刻々と変化する流速脈波の積分 值と血管断面積を同時にコンピューター処理に
よりデジタル表示することは容易なことであ ク，将来，臨床面での応用は充分に期待できる 実用装置となりうると考える。

制辟

稿を䊏るに臨み，愁始想切ていねいなるご指導を 賜った寺本滋教授に深謝するとともに，直接ご援助 とご䩒撻を賜った関洲二講師に深謝致します。また， 工学系に関することでは磨応義塑大学工学部, 藤岡 知夫助教授，ならびに慈恵会医科大学, ME 学教室, 古幡博詩師に厚く感謝致します。さらに実検にあた って協力を惜まれなかった谷崎真行博士，多胡護博 士, 藤田邦雄博士，およU゙第 2 外科教室の諸氏に感 謝の意を表します。

本諭文の要旨は，第 1 回ME学会（中国·四国地 方会)（53年11月）、第20回，日本脈管学会（54年10 月), 日本 $M E$ 学会専門別研究会「心膡血管内の流体 力学と基䂢計測研究会」(54年11月)において哞表した。

本研究の一部は文部省科学研究費補助金 (課題番 号 457327)による.

\section{女}

1. 竹沢英郎：大血管の超音波診断。呼と循, 10, 893-898, 1975.

2. 小向洋一郎：超音波による大功脈の内径，振幅の功態に関する解㹞．日本超音波医学会檴演集 30, 221一 $222,1971$.

3. 長井靖夫：Echocardiography に两大血管の瑟別。日本超音波医学会講演集，26，69-70，1974.

4. Goldberg, B.B.: Ultrasonic measurement of the aortic arch, right pulmonary artery, and left atrium. Radiology 101, 383-392, 1971.

5. Goldberg, B.B.: Suprateral ultrasonography. J. Am. Med. Assoc. 215, 245-250, 1971.

6. Olson, R.M. and Sheltom, D.K.JR.: A nondestructive technique to measure wall displacement in the thoracic aorta. J. Appl. Physiol. 32, 147-152, 1972.

7. Shelton, D.K.JR. and Olson, R.M.: A nondestructive technique to measure variatios. J. Appl. Physiol. 39, 542-550, 1972.

8 . Colocousis, J.S.: Estimation of stroke volume changes by ultrasonic Doppler. Circulation 56, 914$1917,1977$.

9. 渡辺 熙：心エコー法の臨床一超音波診断法の原理一新興医学出版社, 3, 10-25, 1975.

10. 沖野 道：心拍出量の测定. 血流湘定，医学著院，pp. 316-324，1974.

11. 仁村泰治：超音波検查法概説. 綜合䪖床, 22, 1907-1913， 1973.

12. 阿部 㭲：方向指示型超音波ドプラー法. 紜合臨床, 21，2601-2610, 1972.

13. 仁村泰治：超音波ドプラー法の応用一理詥と評洒一，呼吸と循理，22，552-559，1973， 
超音波ドブラー法と超音波カルディオグラフィ法の併用による非観血的心拍出量測定法 683

14. 付村泰治：超音波ドブラー法による血流計測の性格に関する検討，日本超音波医学会請演論文集，27，73 $-74,1970$.

15. 新 真人：超音波血流計の定量化への試み一超音波ビーム角度一，日本超音波医学会講演論文集，24，125 $-126,1968$.

16. 新 真人：超音波血流計の定量化への試み. 日本超音波医学会譜演論文集，28，15-16，1975.

17. 古幡 博：超音波 Doppler 血流計の定量性の限界。 日本超音波医学会請演論文集, 25, 185-186, 1974.

18. 古幡 博：血流速度の絶对值計湖をめさした超音波ドフララー法。医用電子と生体工学、4，264ー268，19 1978.

19. 加藤金正：超音波ドブラー血流計による平均流速計測における必要条件，日本超音波医学会撛演論文集， 27, 75-76, 1970.

20. Bernstein E.F.: Non Invasive Diagnostic Technique in Vascular Disease Mosby, Boston, pp. 11-229, 1978.

21. 伊藤勝售：超音波 Doppler 法による末梢助脈の研究一拍動数の変化に伴う血流速パターンの変化. 日本超 音波医学会撛演論文集，28，21-22，1975.

22. 長鸠孝昌：血行再建術術中後の管理に於ける超音波血流計の応用。日本超音波医学会諾演諭文集，28，15 $-16,1975$.

23. 尾本良三：末梢動脈血流波形による简易デジタル表示心拍出量の試作。日本超音波医学会諈演詅文集，29， 59-60, 1976.

24. 奥田国彦：超音波 Doppler 法による末梢䛻懪に関する研究一高血圧患者の総頚钦脈血流速 Pattern につい て一. 日本超音波医学会諢演譮文集, 24，139-140，1973.

25. 伊藤勝㤵：超音波 Doppler 法による末梢循懪の研究一心血管モデルにおける不均一径管の血流速波形にお よはす影锌一，日本超音波医学会譜演詥文集，29，61-62，1976.

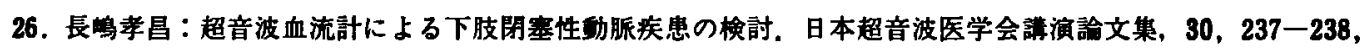
1976.

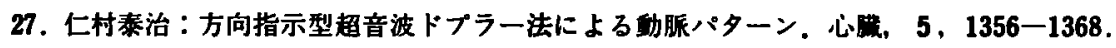

28. Alberto Benchimol: Clinical Application of the Doppler Ultrasonic Flowmeter. Am. J. Cardiol. 29, 540-548, 1972. 
A new non-invasive method for cardiac output measurement by combining an ultrasonic Doppler method to an ultrasonic echocardiography Atsuo OHYA Second Department of Surgery, Okayama University Medical School

(Director : Prof. S. Teramoto)

It is a well-known fact that knowing cardiac output and blood flow volume in a certain region of the body is of importance not only in clinical practice but also in physiology. Furthermore, it would be ideal if they were measured, simply, non-invasively and repeatedly without torture to patients. The ultrasonic Doppler method has been believed to be suitable and modified for this purpose. However, critical shortcoming in this method is that this method lacks quantitative determination because sectional area of the vessels is unknown. This study was to develop a new non-invasive method of determining blood flow volume by combining echocardiography to Doppler method. Echocardiography is able to determine the diameter of the vessels and Doppler method simultaneously determines blood flow velocity in it. Then, blood flow volume becomes obtainable.

This study of applying Doppler and echocardiographic probes in a short interval showed a good correlation of blood flow volume obtained with this method to that obtained with electromagnetic method. It was also found that cardiac output was obtainable by measuring the blood flow volume of the common carotid artery with the method. Correlation coefficient (r) between the diameter obtained by echocardiography and that measured with a ruler was 0.99 with a regression equation of $y=0.89 x+0.22(p<0.001)$. $r$ between blood flow volume obtained with this method and that measured by electromagnetic probe was 0.96 with $\mathrm{y}$ $=0.92 x-0.03(p<0.001)$. Estimation of cardiac output from the blood flow volume of the left common carotid artery, which was determined with this method, was accurate with $\mathbf{r}$ $=0.90(y=37.0 x+18.9, p<0.001)$. With these data, it was concluded that this new method, namely, a combination of Doppler method and echocardiography, was accurate enough to clinical use to determine regional blood flow volume and it was also available to estimate cardiac output from the blood flow volume of the left common carotid artery. Moreover, this new method is measurable repeatedly without invasion and torture to patients with simple technique. 